\title{
Seasonal distribution of multiclass pesticide residues in the surface waters of northwest Croatia
}

\author{
Sanja Fingler, Gordana Mendaš, Marija Dvoršćak, Sanja Stipičević, Želimira Vasilić, and Vlasta \\ Drevenkar
}

Institute for Medical Research and Occupational Health, Zagreb, Croatia

[Received in October 2021; Similarity Check in October 2021; Accepted in November 2021]

\begin{abstract}
As part of our OPENTOX project, we evaluated the incidence and mass concentrations of multiclass pesticide residues in 23 river/stream water samples collected in urban and agricultural areas of northwest Croatia at various points of the pesticide application season in 2015. The study included 16 compounds of five herbicide classes and seven compounds of three insecticide classes. Pesticide residues were accumulated from water by solid-phase extraction and analysed using high performance liquid chromatography with UV-diode array detection and/or gas chromatography-mass spectrometry. Herbicide residues were more common than the insecticide ones, and, as expected, they peaked in the middle of the application season. Metolachlor showed the highest concentrations and was found in $91 \%$ of all samples, followed by terbuthylazine, found in $70 \%$ of the samples. The highest total mass concentration of detected pesticides was measured in the water samples of the Krapina (3992 ng/L) and Sutla (3455 ng/L) collected in rural areas with intensive agriculture. Our findings strongly speak in favour of continued monitoring of surface waters and possibly extending the list of priority water pollutants.
\end{abstract}

KEY WORDS: degradation products; herbicides; insecticides; pesticide residues; river water; seasonal variations

According to European Directive 2013/39/EU (1), nearly a half of the 45 compounds classified as priority water pollutants are legacy or currently used pesticides. In the environment, especially in watercourses flowing through agricultural areas, these pesticides are present in complex mixtures $(2,3)$, whose toxic effects are still insufficiently explored $(4,5)$. Some, such as atrazine, acetochlor, trifluraline, and chlorfenvinphos, have gradually been phased out and eventually banned in many European countries, but their residues and degradation products in water resources have remained a serious issue in different parts of the world (6-12). New pesticide classes that have replaced them have also been contributing to water pollution $(7,8)$.

The aim of this study was to evaluate and compare the burden of selected legacy and current-use pesticides on river/stream waters in urban and rural areas of northwest Croatia as part of the OPENTOX project (2014-2018) investigating pesticide pollution and impact on the environment and human health in a densely populated area of the most developed northwest part of Croatia. Furthermore, we wanted to compare our findings with earlier reports from this area to get a better insight into any trend that may have taken place over the years $(9,13)$.

Corresponding author: Gordana Mendaš, Institute for Medical Research and Occupational Health, Ksaverska cesta 2, 10000 Zagreb, Croatia E-mail: gmendas@imi.hr

\section{MATERIALS AND METHODS}

River/stream water samples were collected in 2015 with a telescopic pole for grab sampling from the bank at a depth of about $0.5 \mathrm{~m}$ as described earlier (9). Figure 1 shows the sampling locations: two at the Sava River a few kilometres upstream and downstream of the Zagreb city centre, two at the mouths of its tributaries Krapina (in Jablanovec) and Sutla (in Harmica), one at the Drava River in the city of Varaždin, two at its tributaries Bednja (in Stažnjevec) and Plitvica (in Greda), and one at the Bednja tributary stream Bistrica (in Ivanec). Of the two major rivers, the Sava springs in Slovenia and flows through rural and urban areas for about $200 \mathrm{~km}$ before it reaches the Croatian capital Zagreb, and the Drava springs in Italy to flow through rural and urban regions in Italy, Austria, and Slovenia for about $420 \mathrm{~km}$ before it reaches Varaždin. The minor rivers Krapina, Sutla, Bednja, Plitvica, and the Bistrica stream flow through semirural/semiurban areas of northwest Croatia dominated by corn fields, orchards, and vineyards.

Sampling was organised around seasonal pesticide application to coincide with its beginning (March), midseason (June), and end (August). The only exception was the Sava 2 location, where we did not collect the August sample.

The samples were stored in 2.5-L tinted glass bottles at $4{ }^{\circ} \mathrm{C}$ until analysis. Water $\mathrm{pH}$ ranged from 6.7 to 7.3. Samples were analysed for 23 pesticides (16 herbicides and 


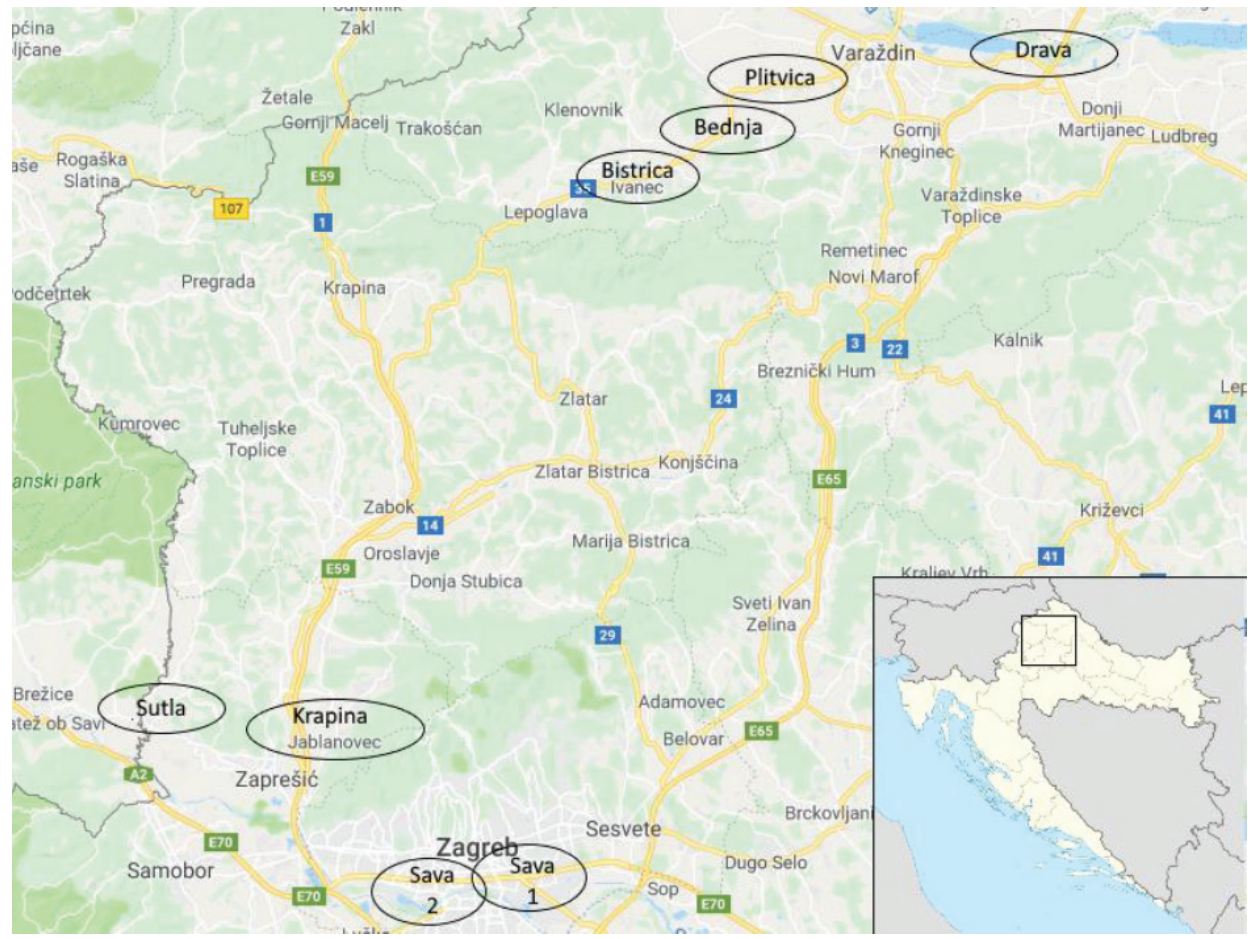

Figure 1 Sampling locations of river/stream waters in northwest Croatia (https://www.google.com/maps/@45.6943072,16.0121326,9z)

seven insecticides) (Table 1), eight of which are listed as priority pollutants (1): alachlor, atrazine, chlorfenvinphos, chlorpyrifos-ethyl, diuron, isoproturon, trifluralin, and cypermethrin. Some of the remaining 15 compounds are allowed for use and are common environmental contaminants in Croatia.

\section{Chemicals}

Atrazine, deethylatrazine (DEA), deisopropylatrazine (DIA), terbuthylazine, deethylterbuthylazine (DET), linuron, diuron, isoproturon, alachlor, trifluralin, chlorpyrifos-ethyl, and chlorfenvinphos were purchased from Riedel de Haën (Seelze, Germany), chlortoluron, mesotrione, tembotrione, 2-amino-4-(methylsulfonyl) benzoic acid (AMBA), and malathion from Sigma Aldrich (Steinheim, Germany), acetochlor from Nitrokémia Environmental Protection Consulting and Ministering Incorporated Company (Füzfőgyártelep, Hungary), metolachlor from Fluka A.G. (Buchs, Switzerland), and $\alpha$-cypermethrin, chlorpyrifos-methyl, chlorpyrifos-methyloxon, and imidacloprid from Dr. Ehrenstorfer (Augsburg, Germany). All these pesticide standards were of $95-100 \%$ purity.

Methanol, acetonitrile, and ethyl acetate for HPLC, LiChrosolv $^{\circledR}$, Suprasolv ${ }^{\circledR}$, and acetone for organic trace analysis were purchased from Merck (Darmstadt, Germany), and orthophosphoric acid (85\%, analytical grade) from Kemika (Zagreb, Croatia). LC-grade water was prepared by purifying deionised water with a Milli-Q water purification system (Millipore, Bedford, MA, USA).

\section{Methods}

Table 2 details five methods used in this study to meet diverse analytical requirements for each compound. For each method we used appropriate single-use solid-phase extraction (SPE) cartridges: $200 \mathrm{mg}$ OASIS HLB (Method 1) and $360 \mathrm{mg} \mathrm{Sep-Pak} \mathrm{C}_{18}$ (Methods 2 and 4) were obtained from Water Associates (Milford, MA, USA) and $200 \mathrm{mg}$ Bakerbond spe ${ }^{\mathrm{TM}}$ SDB-1 (Method 3) and $100 \mathrm{mg} \mathrm{C}$ Polar plus/SDB-1 (Method 5) from JT Baker (Deventer, the Netherlands). The extracts were analysed using highperformance liquid chromatography with UV diode array detection [HPLC-UV(DAD)] and/or by gas chromatography - mass spectrometry using ion trap detection [GCMS(ITD)].

Water extracts were evaporated to dryness under a gentle stream of nitrogen. For HPLC-UV(DAD) analysis, the dry residue was redissolved in $0.5 \mathrm{~mL}$ or $1.0 \mathrm{~mL}$ of deionised water or in a mixture of acetonitrile and deionised water $(\mathrm{pH} 3)$ in the 1:9 ratio. For GC-MS(ITD) analysis, the dry residue was redissolved in $0.5 \mathrm{~mL}$ or $1.0 \mathrm{~mL}$ ethyl acetate. Prior to HPLC-UV(DAD) or GC-MS(ITD) analysis, the extracts were filtered through $0.2 \mu \mathrm{m}$ pore size syringe filters.

HPLC-UV(DAD) analysis was performed on a Varian liquid chromatograph equipped with a Varian ProStar 230 SDM pump, Varian ProStar 410 autosampler employing a $100-\mu \mathrm{L}$ sample loop, and a Varian ProStar 330 photodiodearray detector (Varian, Walnut Creek, CA, USA). The chromatographic column was $\mathrm{Gemini}_{18}, 250 \times 4.6 \mathrm{~mm}$ i.d., of 5- $\mu \mathrm{m}$ particle size with a $4.0 \times 3.0 \mathrm{~mm}$ i.d. guard column of 5- $\mu \mathrm{m}$ particle size (Phenomenex, Torrence, CA, USA). 
Table 1 Pesticides and pesticide degradation products analysed in this study

\begin{tabular}{|c|c|c|c|c|}
\hline Pesticide & Chemical name & $\begin{array}{c}S^{\mathrm{a}} \\
(\mathbf{m g} / \mathbf{L})\end{array}$ & $\log K_{\text {ow }}^{\text {a }}$ & $\mathrm{p} K_{\mathrm{a}}^{\mathrm{a}}$ \\
\hline \multicolumn{5}{|l|}{ Dinitroaniline herbicide } \\
\hline Trifluralin & 2,6-dinitro- $N, N$-dipropyl-4-(trifluoromethyl)aniline & 0.221 & 5.27 & ND \\
\hline \multicolumn{5}{|l|}{$s$-Triazines and metabolites } \\
\hline Atrazine & $\begin{array}{c}\text { 6-chloro- } N^{2} \text {-ethyl- } N^{4} \text {-(1-isopropyl)-1,3,5-triazine-2,4- } \\
\text { diamine }\end{array}$ & 35 & 2.7 & 1.7 \\
\hline Deethylatrazine (DEA) & 6-chloro- $N^{4}$-isopropyl-1,3,5-triazine-2,4-diamine & 2700 & 1.51 & $1.3^{\mathrm{b}}$ \\
\hline Deisopropylatrazine (DIA) & 6-chloro- $N^{2}$-ethyl-1,3,5-triazine-2,4-diamine & 980 & 1.15 & $1.2^{\mathrm{b}}$ \\
\hline Terbuthylazine & 6-chloro- $N^{2}$-tert-buthyl- $N^{4}$-ethyl-1,3,5-triazine-2,4-diamine & 6.6 & 3.4 & 1.9 \\
\hline Deethylterbuthylazine (DET) & 6-chloro- $N^{2}$ - tert-buthyl -1,3,5-triazine-2,4-diamine & 327.1 & 2.3 & $1.35^{\mathrm{c}}$ \\
\hline \multicolumn{5}{|l|}{ Phenylurea herbicides } \\
\hline Diuron & 3-(3,4-dichlorophenyl)-1,1-dimethylurea & 35.6 & 2.87 & ND \\
\hline Linuron & 3-(3,4-dichlorophenyl)-1-methoxy-1-methylurea & 63.8 & 3.0 & ND \\
\hline Chlortoluron & 3-(3-chloro-4-methylphenyl)-1,1-dimethylurea & 76 & 2.5 & ND \\
\hline Isoproturon & 3-(4-isopropylphenyl)-1,1-dimethylurea & 70.2 & 2.5 & ND \\
\hline \multicolumn{5}{|l|}{ Chloroacetanilide herbicides } \\
\hline Acetochlor & $\begin{array}{l}\text { 2-chloro- } N \text {-(ethoxymethyl)- } N \text {-(2-ethyl-6-methylphenyl) } \\
\text { acetamide }\end{array}$ & 282 & 4.14 & ND \\
\hline Alachlor & $\begin{array}{l}\text { 2-chloro- } N \text {-(2,6-diethylphenyl)- } N \text {-(methoxymethyl) } \\
\text { acetamide }\end{array}$ & 240 & 3.09 & 0.62 \\
\hline Metolachlor & $\begin{array}{l}(R S) \text {-2-chloro- } N \text {-(2-ethyl-6-methyl-phenyl)- } N \text {-(1- } \\
\text { methoxypropan-2-yl)acetamide }\end{array}$ & 530 & 3.4 & ND \\
\hline \multicolumn{5}{|l|}{$\begin{array}{l}\text { Triketone herbicides and } \\
\text { metabolite AMBA }\end{array}$} \\
\hline Mesotrione & 2-[4-(methylsulfonyl)-2-nitrobenzoyl]cyclohexane-1,3-dione & 1500 & 0.11 & 3.12 \\
\hline \multirow[t]{2}{*}{$\begin{array}{l}\text { 2-Amino-4-(methylsulfonyl) } \\
\text { benzoic acid (AMBA) }\end{array}$} & 2-amino-4-(methylsulfonyl)benzoic acid & NA & $0.38^{\mathrm{d}}$ & $4.24^{\mathrm{d}}$ \\
\hline & $\begin{array}{l}\text { 2-[2-chloro-4-methylsulfonyl-3-(2,2,2-trifluoroethoxymethyl) } \\
\text { benzoyl]cyclohexane-1,3-dione }\end{array}$ & 71000 & -1.09 & 3.18 \\
\hline
\end{tabular}

\begin{tabular}{|c|c|c|c|c|}
\hline \multicolumn{5}{|l|}{$\begin{array}{l}\text { Organophosphorous } \\
\text { insecticides and oxo- } \\
\text { metabolite }\end{array}$} \\
\hline Chlorpyrifos-methyl & $O, O$-dimethyl $O$-3,5,6-trichloro-2-pyridyl phosphorothioate & 2.74 & 4.00 & ND \\
\hline Chlorpyrifos-ethyl & $O, O$-diethyl $O$-3,5,6-trichloropyridin-2-yl phosphorothioate & 1.05 & 4.7 & ND \\
\hline Chlorpyrifos-methyl-oxon & Dimethyl (3,5,6-trichloropyridin-2-yl) phosphate & NA & $1.91^{\mathrm{e}}$ & NA \\
\hline Malathion & Diethyl 2-[(dimethoxyphosphorothioyl)sulfanyl]butanedioate & 148 & 2.75 & ND \\
\hline Chlorfenvinphos & $\begin{array}{l}{[(E Z) \text {-2-chloro-1-(2,4-dichlorophenyl)ethenyl] diethyl }} \\
\text { phosphate }\end{array}$ & 145 & 3.8 & ND \\
\hline \multicolumn{5}{|l|}{ Pyrethroid insecticide } \\
\hline$\alpha$-Cypermethrin & $\begin{array}{c}\text { Racemate comprising }(R) \text { and }(S) \alpha \text {-cyano-3-phenoxybenzyl- } \\
\text { (1R,3R)-3-(2,2-dichlorovinyl)- 2,2-dimethylcyclopropane- } \\
\text { carboxylate }\end{array}$ & 0.004 & 5.8 & ND \\
\hline \multicolumn{5}{|l|}{ Neonicotinoid insecticide } \\
\hline Imidacloprid & $\begin{array}{l}N \text { - }\{1-[(6-\text { chloro-3-pyridyl)methyl]-4,5-dihydroimidazol-2- } \\
\text { yl }\} \text { nitramide }\end{array}$ & 610 & 0.57 & ND \\
\hline
\end{tabular}

${ }^{\mathrm{a}} K_{\text {ow }}-n$-octanol-water partition coefficient; $\mathrm{p} K_{\mathrm{a}}$ - dissociation constant; NA - not available; ND - no dissociation; $S$ - solubility in water $(14) ;{ }^{\mathrm{b}}(8),{ }^{\mathrm{c}}(15),{ }^{\mathrm{d}}(16),{ }^{\mathrm{e}}(17)$ 
The mobile phase for the analysis of triketone herbicides and their metabolites (Method 1) as well as for the analysis of terbuthylazine, DET, malathion, chlorfenvinphos, imidacloprid, and chlorpyrifos-methyl-oxon (Method 2) consisted of acetonitrile and deionised water acidified with $\mathrm{H}_{3} \mathrm{PO}_{4}$ to $\mathrm{pH}$ 2.2. The compounds were eluted using linear gradient elution mode from $10 \%$ to $80 \%$ acetonitrile over $17 \mathrm{~min}$ (Method 1) and from $20 \%$ to $75 \%$ acetonitrile over 27 min (Method 2). The mobile phase solvents for the analysis of a mixture of $s$-triazines and their metabolites and phenylurea herbicides were acetonitrile and deionised water (Method 3). Herbicides were eluted with a linear gradient from $30 \%$ to $40 \%$ acetonitrile over $22 \mathrm{~min}$ and then from $40 \%$ to $90 \%$ acetonitrile over $8 \mathrm{~min}$ as described elsewhere (9). The mobile phase flow-rate for all methods was $1 \mathrm{~mL} / \mathrm{min}$. The sample volume injected was $100 \mu \mathrm{L}$. The UV-spectra of all analytes were recorded at $200 \mathrm{~nm}$ to $400 \mathrm{~nm}$ (Table 2).

GC-MS(ITD) analysis was performed on a Varian Saturn 2200 GC/MS/MS system consisting of a CP-3800 gas chromatograph with 1079 on-column injector, CP-8410 autoinjector, and ion trap detector. The GC column was an HP-5MS fused silica column, $30 \mathrm{~m}$ x $0.25 \mathrm{~mm}$ i.d., film thickness $0.25 \mu \mathrm{m}$ (Agilent Technologies, Santa Clara, CA, USA). Pesticide compounds were separated and detected under GC-MS(ITD) operating conditions described earlier (9). Their mass spectra were recorded in the full scan acquisition mode (mass range $50-550 \mathrm{~m} / \mathrm{z}$ ) and scan rate of three scans per second. Table 2 lists the most intensive fragment ions $(\mathrm{m} / \mathrm{z})$ selected for the quantitation of specific analytes (Methods 4 and 5).

Standard solutions for HPLC-UV(DAD) analysis were prepared in deionised water and for GC-MS(ITD) analysis in ethyl acetate. Mass concentrations of single pesticides in final HPLC standards ranged from 19 to $536 \mathrm{ng} / \mathrm{mL}$ and in standards for GC analysis from $13 \mathrm{ng} / \mathrm{mL}$ to $929 \mathrm{ng} / \mathrm{mL}$.

For recovery experiments, river water samples were spiked with pesticide standards in aqueous or acetone solutions. Mass concentrations in spiked water samples ranged from 19 to $1429 \mathrm{ng} / \mathrm{L}$ for HPLC-UV(DAD) and from 3 to $1034 \mathrm{ng} / \mathrm{L}$ for GC-MS(ITD). The precision of the methods was determined by calculating the relative standard deviations (RSD) of recoveries obtained by repeated analysis of spiked water samples. In the investigated concentration ranges, pesticide recoveries were almost quantitative for most compounds and ranged from 90 to

Table 2 Methods for determination of pesticides and their degradation products in natural waters by SPE and HPLC-UV(DAD) or GC-MS(ITD) analysis

\begin{tabular}{|c|c|c|c|c|c|}
\hline \multirow{2}{*}{$\begin{array}{l}\text { Method of } \\
\text { analysis }\end{array}$} & \multicolumn{3}{|c|}{ HPLC-UV(DAD) } & \multicolumn{2}{|c|}{ GC-MS(ITD) } \\
\hline & $\begin{array}{c}\text { Method 1 - } \\
\lambda(\mathrm{nm})\end{array}$ & $\begin{array}{c}\text { Method 2 - } \\
\lambda(\mathrm{nm})\end{array}$ & $\begin{array}{c}\text { Method 3 }^{\mathbf{a}}- \\
\lambda(\mathrm{nm})\end{array}$ & $\begin{array}{c}\text { Method } 4^{\mathrm{a}}- \\
\mathrm{m} / \mathrm{z}\end{array}$ & $\begin{array}{l}\text { Method } 5 \text { - } \\
\quad m / z\end{array}$ \\
\hline \multirow{9}{*}{ Pesticide } & $\begin{array}{l}\text { Mesotrione - } \\
220\end{array}$ & Terbuthylazine - 222 & Atrazine -222 & $\begin{array}{l}\text { Trifluralin - } \\
264\end{array}$ & $\begin{array}{c}\text { Terbuthylazine } \\
-214\end{array}$ \\
\hline & AMBA - 220 & DET - 214 & DEA - 214 & Atrazine - 200 & $\begin{array}{l}\text { Chlorpyrifos- } \\
\text { methyl - } 286\end{array}$ \\
\hline & $\begin{array}{l}\text { Tembotrione } \\
-205\end{array}$ & Malathion - 205 & DIA - 214 & $\begin{array}{c}\text { Terbuthylazine } \\
-214\end{array}$ & $\begin{array}{l}\text { Chlorpyrifos- } \\
\text { ethyl - } 314\end{array}$ \\
\hline & & Chlorfenvinphos - 205 & Terbuthylazine - 222 & $\begin{array}{c}\text { Acetochlor - } \\
223\end{array}$ & Malathion - 173 \\
\hline & & $\begin{array}{l}\text { Chlorpyrifos-methyl- } \\
\text { oxon }-205\end{array}$ & DET - 214 & Alachlor - 188 & $\begin{array}{c}\text { Chlorfenvinphos } \\
-267\end{array}$ \\
\hline & & Imidacloprid - 270 & Diuron - 210, 245 & $\begin{array}{l}\text { Metolachlor } \\
-162\end{array}$ & $\begin{array}{c}\alpha \text {-Cypermethrin } \\
-163\end{array}$ \\
\hline & & & Linuron $-210,245$ & & \\
\hline & & & $\begin{array}{l}\text { Chlortoluron - } \\
210,245\end{array}$ & & \\
\hline & & & $\begin{array}{c}\text { Isoproturon }-202, \\
245\end{array}$ & & \\
\hline SPE & OASIS HLB & $\mathrm{C}_{18}$ & SDB-1 & $\mathrm{C}_{18}$ & $\begin{array}{l}\text { C18 Polar plus/ } \\
\text { SDB-1 }\end{array}$ \\
\hline Activation & $\mathrm{MeOH}+\mathrm{H}_{2} \mathrm{O}$ & $\mathrm{ACN}+\mathrm{H}_{2} \mathrm{O}$ & $\mathrm{MeOH}+\mathrm{H}_{2} \mathrm{O}$ & $\mathrm{MeOH}+\mathrm{H}_{2} \mathrm{O}$ & $\mathrm{MeOH}+\mathrm{H}_{2} \mathrm{O}$ \\
\hline $\begin{array}{l}\text { Solvent } \\
\text { volume }(\mathrm{mL})\end{array}$ & $2+2$ & $5+5$ & $2+5$ & $2+5$ & $2+5$ \\
\hline $\begin{array}{l}\text { Sample } \\
\text { volume }(\mathrm{mL})\end{array}$ & 500 & 500 & 500 & 1000 & 500 \\
\hline Eluent & $\mathrm{MeOH}$ & ACN+Et.ac & $\mathrm{Ac}$ & Et.ac & Et.ac \\
\hline $\begin{array}{l}\text { Eluent volume } \\
(\mathrm{mL})\end{array}$ & 10 & $10+5$ & 2 & 2 & 10 \\
\hline
\end{tabular}

Ac-acetone; $\mathrm{ACN}$ - acetonitrile; Et.ac - ethyl acetate; $\mathrm{MeOH}$ - methanol; $m / z$ - significant MS fragment ion selected for quantitation; ${ }^{\text {a }}$ as described in (9) 
$107 \%$. The only exceptions were the slightly lower but still satisfactory recoveries of chlorfenvinphos $(78 \%)$ and imidacloprid ( $87 \%$ ) analysed by Method 2 and of atrazine (82\%), terbuthylazine $(87 \%)$, linuron $(84 \%)$, and isoproturon ( $88 \%$ ) analysed by Method 3. Low relative standard deviations of recoveries $(<1-13 \%)$ confirmed good precision of all methods.

Pesticides in river/stream water samples were quantified by external calibration with multipoint calibration lines generated daily for each compound by linear regression of its standard concentrations and the corresponding peak areas. Solvent and reagent blanks were prepared with each set of five water samples and analysed in the same manner as water extracts.

All analyses were run in duplicate. The target analytes were identified by comparing their chromatographic retention times and the corresponding UV or MS spectra with those of the known standards.

The limit of detection (LOD), defined as the average blank value plus three standard deviations (average $+3 \sigma$ ), was also used as the limit of quantitation (LOQ). The LOD of the GC-MS(ITD) method ranged from 5 to $30 \mathrm{ng} / \mathrm{L}$, while the LOD of HPLC ranged from 10 to $15 \mathrm{ng} / \mathrm{L}$.

\section{RESULTS AND DISCUSSION}

Of the 23 analysed pesticide pollutants, eight were not detected in any water samples, namely trifluralin, alachlor, malathion, chlortoluron, linuron, chlorpyrifos-ethyl, chlorfenvinphos, and $\alpha$-cypermethrin. Negative findings for the first three pesticides are in line with their ban in Croatia since 2009, but the other five were still legal to use back in 2015 (18).

Among the 15 pesticide compounds detected in our river/stream water samples, 12 were herbicides and their degradation products and only three were insecticides. The number of positive water samples in all three sampling rounds and mass concentrations of detected pesticide residues are shown in Table 3. Six pesticide compounds were detected in more than half of the analysed samples: metolachlor in $91 \%$, DEA and terbuthylazine in $70 \%$, atrazine in $65 \%$, DIA in $57 \%$, and chlorpyrifos-methyloxon in $52 \%$.

Atrazine and acetochlor were also found, although their use has been banned in Croatia since 2009 and 2014, respectively. While the possibility of illegal leftover use cannot be completely ruled out, as may be the case with acetochlor found in only one sample in June (see Table 3), a more likely explanation for the relatively high incidence of atrazine and its degradation products DEA and DIA is their persistence in treated agricultural soils resulting in prolonged water pollution in agricultural catchments $(8,19$, 20).

Most pesticides were identified in the height of the application season (14 in June as opposed to nine in March and eight in August) (Table 3).

Of the priority water pollutants, we found only atrazine, isoproturon, and diuron, and their peak mass concentrations were one to two orders of magnitude lower than the maximum allowable concentrations defined by the Directive

Table 3 Mass concentrations of pesticide pollutants in river/stream water samples collected in the northwest part of Croatia across application season

\begin{tabular}{|c|c|c|c|c|c|c|c|c|c|}
\hline \multirow{3}{*}{ Pesticide compound } & \multicolumn{3}{|c|}{$\operatorname{March} 2015(N=8)$} & \multicolumn{3}{|c|}{ June $2015(N=8)$} & \multicolumn{3}{|c|}{ August $2015(N=7)$} \\
\hline & \multirow[b]{2}{*}{$n$} & \multicolumn{2}{|c|}{$\gamma(\mathrm{ng} / \mathrm{L})$} & \multicolumn{3}{|c|}{$\gamma(\mathrm{ng} / \mathrm{L})$} & \multicolumn{3}{|c|}{$\gamma(\mathrm{ng} / \mathrm{L})$} \\
\hline & & Range $^{a}$ & Median $^{\mathrm{b}}$ & $n$ & Range $^{a}$ & Median $^{\mathrm{b}}$ & $n$ & Range $^{a}$ & Median $^{\mathrm{b}}$ \\
\hline Mesotrione & 0 & & & 3 & $36-107$ & 0 & 0 & & \\
\hline Tembotrione & 0 & & & 7 & $51-216$ & 77 & 0 & & \\
\hline AMBA & 0 & & & 6 & $54-444$ & 74 & 1 & 61 & $<\mathrm{LOD}$ \\
\hline Terbuthylazine & 3 & $9-13$ & $<\mathrm{LOD}$ & 8 & $20-419$ & 42 & 5 & $10-26$ & 13 \\
\hline DET & 1 & 9 & $<\mathrm{LOD}$ & 4 & $38-200$ & 19 & 2 & $14-45$ & $<\mathrm{LOD}$ \\
\hline Atrazine & 5 & $10-16$ & 11 & 5 & $12-34$ & 13 & 5 & $9-24$ & 14 \\
\hline DIA & 5 & $5-32$ & 6 & 6 & $17-123$ & 28 & 2 & $19-24$ & $<\mathrm{LOD}$ \\
\hline DEA & 4 & $8-11$ & 4 & 7 & $7-24$ & 11 & 5 & $6-32$ & 10 \\
\hline Isoproturon & 1 & 146 & $<\mathrm{LOD}$ & 0 & & & 0 & & \\
\hline Diuron & 0 & & & 2 & $22-30$ & $<\mathrm{LOD}$ & 0 & & \\
\hline Acetochlor & 0 & & & 1 & 28 & $<\mathrm{LOD}$ & 0 & & \\
\hline Metolachlor & 7 & $9-11$ & 9 & 8 & $11-3015$ & 147 & 6 & $10-63$ & 11 \\
\hline Chlorpyrifos-methyl & 0 & & & 1 & 26 & $<\mathrm{LOD}$ & 0 & & \\
\hline Chlorpyrifos-methyl-oxon & 1 & 21 & $<\mathrm{LOD}$ & 8 & $23-145$ & 64 & 3 & $34-198$ & $<\mathrm{LOD}$ \\
\hline Imidacloprid & 1 & 73 & $<\mathrm{LOD}$ & 8 & $12-34$ & 26 & 0 & & \\
\hline
\end{tabular}

$\overline{N \text { - number of samples; } n \text { - number of positive samples; LOD - limit of detection; }{ }^{\mathrm{a}} \text { Range applies to positive samples, }{ }^{\mathrm{b}} \text { Median applies }}$ to all samples 


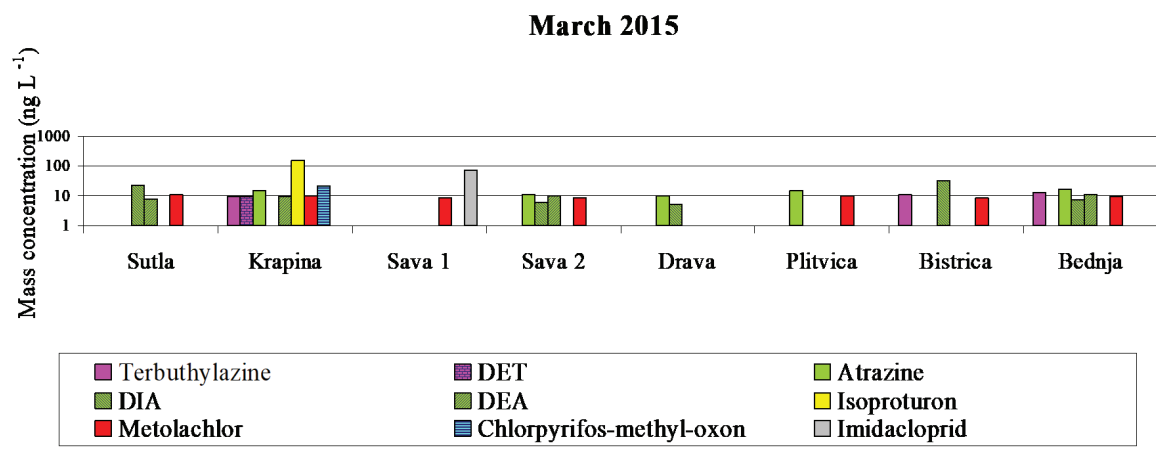

June 2015
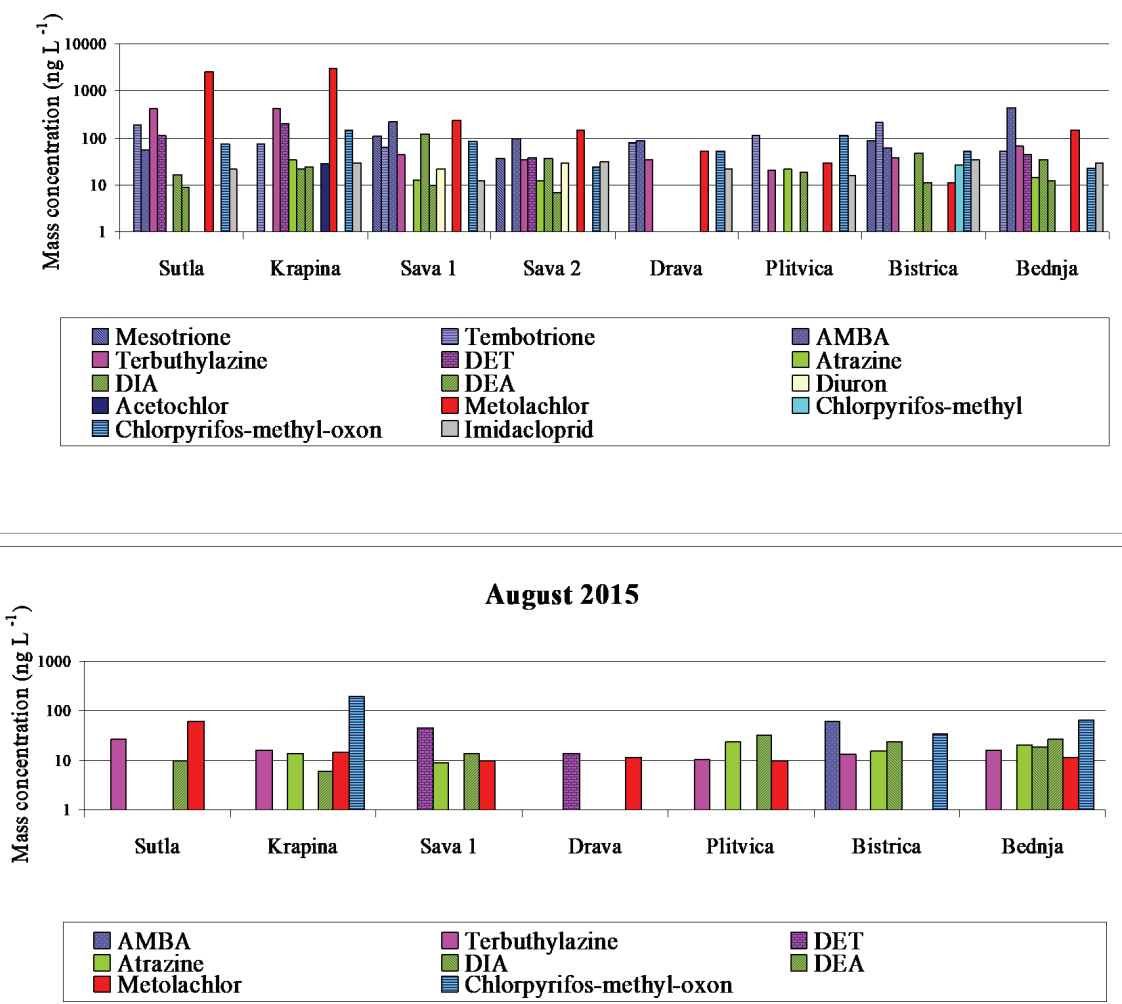

Figure 2 Mass concentrations of individual pesticides determined in river/stream water samples collected at the beginning (March), peak (June), and end (August) of the 2015 pesticide application season. AMBA - 2-amino-4-(methylsulfonyl)benzoic acid; DEA deethylatrazine; DET - deethylterbuthylazine; DIA - deisopropylatrazine

as Environmental Quality Standards for surface waters (1). As there are no limits for pesticide compounds not considered priority pollutants, their mass concentrations in surface waters are often considered in terms of maximum permissible mass concentrations in water intended for human consumption of $100 \mathrm{ng} / \mathrm{L}$ for single pesticides and $500 \mathrm{ng} / \mathrm{L}$ for total pesticides (21). In this regard, Figure 2 shows that the $100 \mathrm{ng} / \mathrm{L}$ limit was mostly exceeded in the middle of the application season.

Table 4 also clearly illustrates seasonal variations in pesticide load by sampling locations. The sum of mass concentrations of detected pesticides was the lowest at the beginning (March) and the highest in the peak of the pesticide application season (June). As expected, the lowest sums of pesticide mass concentrations were measured in the Drava River sampled in the urban area and the highest in the Krapina and Sutla rivers sampled in rural areas with intensive agricultural production. In the peak of the pesticide season, it exceeded the $500 \mathrm{ng} / \mathrm{L}$ limit for drinking water (21) in the samples taken from the Sutla, Krapina, Sava, and Bednja and the Bistrica stream. Metolachlor and terbuthylazine accounted for the largest shares in total mass concentrations in the Krapina and Sutla, metolachlor with $76 \%$ and $74 \%$ and terbuthylazine with $10 \%$ and $12 \%$, respectively (see Figure 2, June). In the Sava, the highest shares were those of metolachlor and AMBA, ranging 
Table 4 Number $(N)$ of individual pesticide compounds, their mass concentration range, and the sum of pesticides mass concentrations $\left(\sum\right)$ by river/stream across application season

\begin{tabular}{|c|c|c|c|c|c|c|c|c|c|c|c|c|}
\hline \multirow{3}{*}{ River/Stream } & \multicolumn{4}{|c|}{ March 2015} & \multicolumn{4}{|c|}{ June 2015} & \multicolumn{4}{|c|}{ August 2015} \\
\hline & \multirow{2}{*}{$N$} & \multicolumn{3}{|c|}{$\gamma(\mathrm{ng} / \mathrm{L})$} & \multirow{2}{*}{$N$} & \multicolumn{3}{|c|}{$\gamma(\mathrm{ng} / \mathrm{L})$} & \multirow{2}{*}{$N$} & \multicolumn{3}{|c|}{$\gamma(\mathrm{ng} / \mathrm{L})$} \\
\hline & & Min & Max & $\sum$ & & Min & Max & $\sum$ & & Min & Max & $\sum$ \\
\hline Sutla & 3 & 8 & 22 & 41 & 9 & 9 & 2564 & 3455 & 3 & 10 & 63 & 99 \\
\hline Krapina & 7 & 9 & 146 & 219 & 10 & 22 & 3015 & 3992 & 5 & 6 & 198 & 248 \\
\hline Sava 1 & 2 & 9 & 73 & 81 & 11 & 10 & 242 & 947 & 4 & 9 & 45 & 77 \\
\hline Sava 2 & 4 & 6 & 11 & 35 & 11 & 7 & 149 & 498 & \multicolumn{4}{|c|}{- not analysed - } \\
\hline Drava & 2 & 5 & 10 & 15 & 6 & 22 & 86 & 323 & 2 & 11 & 14 & 25 \\
\hline Plitvica & 2 & 10 & 16 & 25 & 7 & 16 & 115 & 331 & 4 & 10 & 32 & 76 \\
\hline Bistrica & 3 & 9 & 32 & 52 & 10 & 11 & 216 & 582 & 5 & 13 & 61 & 147 \\
\hline Bednja & 5 & 7 & 16 & 56 & 10 & 12 & 444 & 867 & 6 & 11 & 66 & 161 \\
\hline
\end{tabular}

Bolded values exceed the EU Directive 2020/2184 limits for total pesticide concentrations in water intended for human consumption (21)

between the two sampling locations with $26-30 \%$ and 20-24\%, respectively. The same pollutants were also dominant in the Bednja, where AMBA and metolachlor accounted for $51 \%$ and $17 \%$, respectively. The high shares of AMBA point to recent application and subsequent degradation of a triketone herbicide mesotrione, which is less stable in soil and water than its degradation product $(8$, 22). As for the Bistrica stream, the highest shares in the sum of pesticide mass concentrations were those of tembotrione and mesotrione with $37 \%$ and $15 \%$, respectively. All these findings point to the prevalence of herbicides metolachlor, terbuthylazine, tembotrione, and mesotrione in pesticide application in northwest Croatia.

The prevalence of metolachlor and terbuthylazine and their degradation products has already been noted in our earlier study of the Sava samples taken the year before (9) and earlier studies across Europe (2, 23-25).

As for insecticides analysed herein, all water samples collected in the height of the pesticide application season (June) contained trace concentrations of imidacloprid and chlorpyrifos-methyl-oxon (Table 3 and Figure 2). The finding of the latter points to a recent use of its parent compound chloropyrifos-methyl. Not only is it more persistent than the parent pesticide [over four weeks, according to Lacorte and Barceló (26)] but it is also more toxic to aquatic organisms and the environment (4) and should be regarded as pollutant of concern. As for the low imidacloprid concentrations, they are likely the consequence of restricted use in Croatia since 2013.

\section{CONCLUSION}

The limitation of our study is that our current data are limited to the measurements taken in 2015, while further data from the OPENTOX project (concluded with 2018) are still pending. Despite this limitation, the study has confirmed the persistence of atrazine in water environment and the domination of herbicide over insecticide use in urban and agricultural areas of northwest Croatia. Our findings further emphasise the need to extend regular monitoring of pesticides in surface waters to herbicide and insecticide compounds that are not considered priority water pollutants at the moment but are frequently used in larger amounts in regions with intensive agriculture. A systematic and regular monitoring of frequently used pesticides in surface waters can inform pesticide users and authorities and help to prevent or at least reduce their adverse effects on aquatic organisms and environment in a timely manner.

\section{Acknowledgements}

This study was supported in part by the Croatian Science Foundation under the project No. 8366 "Organic Pollutants in Environment - Markers and Biomarkers of Toxicity (OPENTOX)".

\section{Conflicts of interest}

None to declare.

\section{REFERENCES}

1. EU Directive 2013/39/EU of the European Parliament and of the Council of 12 August 2013 amending Directives 2000/60/EC and 2008/105/EC as regards priority substances in the field of water policy Text with EEA relevance [displayed 23 August 2021]. Available at https://eur-lex. europa.eu/legal-content/EN/ALL/?uri=CELEX:32013L0039

2. Casado J, Santillo D, Johnston P. Multi-residue analysis of pesticides in surface water by liquid chromatography quadrupole-Orbitrap high resolution tandem mass spectrometry. Anal Chim Acta 2018;1024:1-17. doi: 10.1016/j.aca.2018.04.026

3. Fonseca E, Renau-Pruñonosa A, Ibáñez M, Gracia-Lor E, Estrela T, Jiménez S, Perez-Martin MA, González F, Hernández F, Morell I. Investigation of pesticides and their transformation products in the Júcar River Hydrographical Basin (Spain) by wide-scope high-resolution mass 
spectrometry screening. Environ Res 2019;177:108570. doi: 10.1016/j.envres.2019.108570

4. Herrero-Hernández E, Simón-Egea AB, Sánchez-Martin MJ, Rodrigues-Cruz S, Andrades MS. Monitoring and environmental risk assessment of pesticide residues and some of their degradation products in natural waters of the Spanish vineyard region included in the Denomination of Origin Jumilla. Environ Pollut 2020;264:114666. doi: 10.1016/j. envpol.2020.114666

5. Papadakis EN, Vryzas Z, Kotopoulou A, Kintzikoglou K, Makris KC, Papadopoulou-Mourkidou E. A pesticides monitoring survey in rivers and lakes of northern Greece and its human and ecotoxicological risk assessment. Ecotoxicol Environ Saf 2015;116:1-9. doi: 10.1016/j.ecoenv.2015.02.033

6. Starner K, Goh KS. Detections of the neonicotinoide insecticide imidacloprid in surface waters of three agricultural regions of California, USA, 2010-2011. Bull Environ Contam Toxicol 2012;88:316-21. doi: 10.1007/s00128-0110515-5

7. Bottoni P, Grenni P, Lucentini L, Barra Caracciolo A Terbuthylazine and other triazines in Italian water resources. Microchem J 2013;107:136-42. doi: 10.1016/j. microc.2012.06.011

8. Barchanska H, Sajdak M, Szczypka K, Swientek A, Tworek M, Kurek M. Atrazine, triketone herbicides, and their degradation products in sediment, soil and surface water samples in Poland. Environ Sci Pollut Res 2017;24:644-58. doi: 10.1007/s11356-016-7798-3

9. Fingler $\mathrm{S}$, Mendaš G, Dvoršćak $\mathrm{M}$, Stipičević S, Vasilić Ž, Drevenkar V. Herbicide micropollutants in surface, ground and drinking waters within and near the area of Zagreb, Croatia. Environ Sci Pollut Res 2017;24:11017-30. doi: 10.1007/s11356-016-7074-6

10. Struger J, Grabuski J, Cagampan S, Sverko E, McGoldrick $\mathrm{D}$, Marvin $\mathrm{CH}$. Factors influencing the occurrence and distribution of neonicotinoid insecticides in surface waters of southern Ontario, Canada. Chemosphere 2017;169:516 23. doi: 10.1016/j.chemosphere.2016.11.036

11. Tang W, Wang D, Wang J, Wu Z, Li L, Huang M, Xu S, Yan D. Pyrethroid pesticide residues in the global environment: An overview. Chemosphere 2018;191:990-1007. doi: 10.1016/j.chemosphere.2017.10.115

12. Tankiewicz M, Biziuk M. Fast, sensitive and reliable multiresidue method for routine determination of 34 pesticides from various chemical groups in water samples by using dispersive liquid-liquid microextraction coupled with gas chromatography-mass spectrometry. Anal Bioanal Chem 2018;410:1533-50. doi: 10.1007/s00216-017-0798-4

13. Drevenkar V, Fingler S, Mendaš G, Stipičević S, Vasilić Ž. Levels of atrazine and simazine in waters in the rural and urban areas of North-West Croatia. Int J Environ Anal Chem 2004;84:207-16. doi: 10.1080/0306731031000149679

14. IUPAC. The PPDB (Pesticide Properties Data Base) [displayed 23 August 2021]. Available at https://sitem.herts. ac.uk/aeru/iupac/atoz.htm

15. Colombini MP, Fuoco R, Giannarelli S, Pospíšil L, Trsková R. Protonation and degradation reactions of s-triazine herbicides. Microchem J 1998;59:239-45. doi: 10.1006/ mchj.1998.1612
16. Barchanska H, Kowalska A, Poloczek B. Extraction procedures for the study of phytotoxicity and degradation processes of selected triketones in a water ecosystem. Environ Sci Pollut Res 2014;21:4751-8. doi: 10.1007/s11356-013$2425-\mathrm{Z}$

17. Safety data sheet for chlorpyrifos-methyl-oxon according to 1907/2006/EC, Article 31 [displayed 23 August 2021]. Available at https://cymitquimica.com/ products/04-C11601500/5598-52-7/chlorpyrifos-methyloxon

18. Marić Ivandija B, Ivandija T. Sredstva za zaštitu bilja 2015 [Plant protection products 2015, in Croatian]. Glasnik zaštite bilja 2015;38(1-2):14-228.

19. Baran N, Mouvet C, Négrel Ph. Hydrodynamic and geochemical constraints on pesticide concentrations in the groundwater of an agricultural catchment (Brévilles, France). Environ Pollut 2007;148:729-38. doi: 10.1016/j. envpol.2007.01.033

20. Amalric L, Mouvet C, Pichon V, Bristeau S. Molecularly imprinted polymer applied to the determination of the residual mass of atrazine and metabolites within an agricultural catchment (Brévilles, France). J Chromatogr A 2008;1206:95104. doi: 10.1016/j.chroma.2008.08.034

21. EU Directive 2020/2184/EU of the European Parliament and of the Council of 16 December 2020 on the quality of water intended for human consumption (recast) (Text with EEA relevance) [displayed 23 August 2021]. Available at https:// e u r - l ex. europa.e u/legal-content/EN/ $\mathrm{TXT} /$ ?uri=CELEX\%3A32020L2184

22. Barchanska H, Rusek M, Szatkowska A. New procedures for simultaneous determination of mesotrione and atrazine in water and soil. Comparison of the degradation processes of mesotrione and atrazine. Environ Monit Assess 2012;184:32134. doi: 10.1007/s10661-011-1970-5

23. Herrero-Hernández E, Rodríguez-Cruz MS, Pose-Juan E, Sánchez-González S, Andrades MS, Sánchez-Martín MJ. Seasonal distribution of herbicide and insecticide residues in the water resources of the vineyard region of La Rioja (Spain). Sci Total Environ 2017;609:161-71. doi: 10.1016/j. scitotenv.2017.07.113

24. De Liguoro M, Dalla Bona M, Gallina G, Capolongo F, Gallocchio F, Binato G, Di Leva V. A monitoring of chemical contaminants in waters used for field irrigation and livestock watering in the Veneto region (Italy) using bioassays as a screening tool. Environ Sci Pollut Res 2014;21:3546-57. doi: 10.1007/s11356-013-2357-7

25. Bono L, Magi E. Fast and selective determination of pesticides in water by automated on-line solid phase extraction liquid chromatography tandem mass spectrometry. Anal Lett 2013;46:1467-76. doi: 10.1080/00032719. 2013.769263

26. Lacorte S, Barceló D. Determination of organophosphorus pesticides and their transformation products in river waters by automated on-line solid-phase extraction followed by thermospray liquid chromatography-mass spectrometry. J Chromatogr A 1995;712:103-12. doi: 10.1016/00219673(95)00425-M 


\section{Sezonska raspodjela različitih klasa pesticida u površinskim vodama sjeverozapadne Hrvatske}

U sklopu našega projekta OPENTOX odredili smo masene koncentracije ostataka pesticida i njihovu učestalost u 23 uzorka vode rijeka/potoka u gradskim i ruralnim dijelovima sjeverozapadne Hrvatske, prikupljenih 2015. tijekom sezone njihove primjene. Istraživanje je obuhvatilo 16 spojeva iz pet različitih klasa herbicida i sedam spojeva iz triju klasa insekticida. Ostaci pesticida akumulirani su iz vode postupkom ekstrakcije na čvrstoj fazi i analizirani tekućinskom kromatografijom visoke djelotvornosti uz UV-detektor s nizom dioda ili vezanim sustavom plinske kromatografije i spektrometrije masa. Češće su detektirani ostatci herbicida nego insekticida, a najviše su koncentracije bile sredinom sezone njihove primjene. Metolaklor je određen u najvišoj koncentraciji i u najvećem broju uzoraka (91 \%), a slijedio ga je terbutilazin, koji je nađen u $70 \%$ uzoraka. Najviša ukupna razina određivanih pesticida bila je u uzorcima rijeka Krapine (3992 ng/L) i Sutle (3455 ng/L), koji su bili prikupljeni u ruralnom području s intenzivnom poljoprivredom. Rezultati našega istraživanja govore $\mathrm{u}$ prilog potrebi ne samo za kontinuiranim monitoringom pesticida u površinskim vodama nego i za proširenjem liste prioritetnih zagađivala.

KLJUČNE RIJEČI: herbicidi; insekticidi; ostaci pesticida; razgradni produkti; riječna voda; sezonske varijacije 